\title{
Legal Protection of Vehicle Users by Under Age (Minors) Viewed from The Perspective at Present Act No.22 of 2009 on Traffic and Transportation
}

\section{Suwitno ${ }^{1}$}

Abstract. The research problems are how the legal protection of motorists under the age of the offenses traffic violations and how efforts and the role of the police in dealing with traffic violations committed minors. Research result This is the legal protection of motorists under the age of criminal acts against traffic violations that should Criminal sanctions imposed on the child must be based on truth, justice, and child welfare. Criminal punishment or actions to be accountable and beneficial for children. The judge shall consider the situation of children, the state house, state of the environment, and social counselors report. Children who are no older than twelve (12) years, although with a criminal offense can not be put on trial the child. The effort and the role carried out by the police in tackling traffic offenses committed by children under age (minors) namely with the preventive and repressive efforts.

Keywords: Legal Protection; Minors; Traffic Law.

\section{Introduction}

The role of law in the nation's development will bring the consequences of the process of change and renewal of existing institutions, including the function of law and in the implementation of development policies of the nation. ${ }^{2}$ Indonesia is a country of law essentially serves as a protector of human law that human interests are protected, the law should be implemented. Implementation of the law can occur normally, but may also occur because of broken the law. ${ }^{3}$ Every citizen is obliged to "respect the law". Daily reality, citizens are negligent or deliberately does not carry out its obligations to the detriment of the society, said that the citizens of the "unlawful" because of the liability has been determined by law. ${ }^{4}$

Attitude problem traffic is already a common phenomenon in major cities in countries that are developing. This problem is often associated with increasing the number of city dwellers who lead the increasing activity and density on the highway. Vehicle traffic diverse and the number of vehicles faster than the accretion of roads that lead to various problems like traffic congestion and traffic accidents.

\footnotetext{
${ }^{1}$ Student of Masters (S2) of Law Faculty of Law Unissula Semarang and Police of Cirebon-POLRI email witno.polri@gmail.com

2 Ediwarman 2014 Penegakan Hukum dalam Perspektif Kriminologi Genta Publishing Yogyakarta 2014 p.31

3 Ibid p.37.

4 Leden Marpaung 2011 Proses Penanganan Perkara Pidana (Penyidikan dan Penyelidikan) Cetakan Ketiga Jakarta Sinar Grafika p. 22
} 
In Act No. 22 of 2009 on Traffic and Transport road, set all the provisions concerning the driver. Article 1 point 23 of this law determines that the driver is a "person driving a motor vehicle on a highway that already have a driving license". As for the driver requirements, set forth in Chapter VIII, namely Article 7 on Article 80 of the same chapter also regulates the classification of driving license (SIM), which consists of a driver's license, SIM BI, SIM B II, SIM C and SIM D. ${ }^{5}$

In today's not just adults who commit traffic violations but also school children who are minors, their consciousness in traffic is still low seen from the data Police Police Cirebon city that the high number of students of junior and senior high traffic violations throughout 2018 in the city of Cirebon. There are 25 cases in the period from January 2108 until May 2018. Children as young generation is a potential successor to the future goals of national struggle. Children is a development that will preserve capital, maintain and develop the existing development results. Children need protection in order to ensure the growth and development of physical, mental, and social whole, harmonious and balanced. ${ }^{6}$

Kids are an integral part of human survival and sustainability of a nation. Kids have a strategic role as expressly stated that the state guarantees the right of every child to survival, grow, and develop as well as protection from violence and discrimination, therefore, the best interests of children should be lived as the best interests of the survival of humanity. The consequences of the provisions of Article $28 \mathrm{~B}$ of the Constitution of the Republic of Indonesia Of 1945 needs to be followed up by making government policies that aim to protect the Child. ${ }^{7}$

The law is not a static thing, the law from time to time is always progressing. This is a logical consequence due to the growth and development of the law itself is influenced by factors. The current law does not appear suddenly so alone, but is the result of a separate development, it is meant that there is a close relationship and reciprocity between law and society. It was supposed to happen this way because after the existence of the law, especially in the community.

Discussion about the purpose of the law is often separated from discussion about legal functions. Things like this according to Ahmad Ali less precise, because in any case the relationship between law purposes with the function of law is a very erat.Yang linkage is first to note, of course, is the purpose of the law, because only the stipulation of what the objectives of the law that, we can also determine the functions to be executed laws in order to achieve its objectives. ${ }^{8}$

Based on the description above, the formulation of problem in this research is How the legal protection of underage users of motor vehicles against traffic violations a criminal offense ?; and How the efforts and role of the police in dealing with traffic violations committed minors?

\footnotetext{
${ }^{5}$ Act No. 22 of 2009 on Traffic and Transportation

${ }^{6}$ Darwan Prinst 1997 Hukum Anak di Indonesia PT. Citra Aditya Bakti Bandung p. 2.

${ }^{7}$ Explanation of the General section of Act No. 11 of 2012 on Criminal By Children Court system.

${ }^{8}$ Achmad Ali 1997 Menguak Takbir Hukum,(Jakarta : Grafindo persada p. 55
} 


\section{Results And Discussion}

\subsection{Overview Traffic Violations}

Traffic is the movement of vehicles, people and animals on the road. In conducting the traffic required a rule that can be used to provide guidance the people in traffic, so traffic violations do not occur. However, despite various regulations have been made, it remains Traffic violations are common, even sedikityang not cause a traffic accident. As we know, the definition of infringement is an act (matter) in violation of criminal offenses are lighter than the crime. ${ }^{9}$ Therefore, if someone has violated a rule that has been made by the government, for example in the case of traffic violations, then it will be known to him by penalties consistent with what his do. Traffic Violations is an act that is contrary to the rules of traffic and or implementation, either can or can not cause any harm people or objects and also kamtibcarlantas. ${ }^{10}$

Traffic violations are not regulated in the Criminal Code but there are concerns the socalled offenses in the Criminal Code, for example, in negligence causing death of person (Article 359), because mislead others were seriously injured (Article 360), due to negligence causing buildings, tram railways, telegraph, telephone, and electricity so destroyed or damaged (Article 409). ${ }^{11}$

The definition and understanding of the crime of traffic violations according to Ramlan Naning, is an act or actions that on contrary to provisions of laws and regulations of road traffic violations in question are as mentioned in the Act No. 22 of 2009 on Traffic and Transportation Article 326, if the provisions terseebut violated, and is classified as a violation. The types of traffic violations in a decree supreme court, Minister of Justice, General Attorney, and the Chief of Police of the Republic of Indonesia on 23 December 1992 stated there were 27 types of violations that are classified into three parts: The classification of minor offenses, classification of violations were and Classification of gross violations

In Act No. 22 of 2009 on Traffic and Transportation, that the provisions of Article 316 paragraph (1) of Act No. 22 of 2009 on traffic and road transport, it can be seen clearly on the articles that have been set up on offense last cross, among others: the provisions referred to in Article 281 to Article 313.

\subsection{Definition of the Child}

- According to the Criminal Code and the Civil Code. In the Code of Penal Article 72 provides an age limit of a child only 16 (sixteen) years, and Article 283 paragraph (1) which provides that the age of the child is not yet reached 17 (seventeen) years, while the Book Civil Law Act (Civil Code), they are immature are those who have not

\footnotetext{
${ }^{9}$ Poerwadarminta 2002 Kamus Besar Bahasa Indonesia Jakarta: Balai Pustaka p.67

${ }^{10}$ Markas Besar Kepolisian Negara Republik Indonesia Akademi Kepolisian 2009 Fungsi Teknis Lalu Lintas Semarang: kompetensi Utama p. 6

${ }^{11}$ Moeljatno 2008 Asas-Asas Hukum Pidana Jakarta: Rieneka Cipta p.23
} 
even reached the age of 21 (twenty-one) years and have never been married are considered incompetent to perform an act of law.

- Based on Act No. 4 of 1979 About Welfare of the Child. Article 1 paragraph 2, explained that "the Son is a person who has not attained the age of 21 (twenty-one) years and have never been married". ${ }^{12}$

- Based on Act No. 35 of 2014 concerning Child Protection. Article 1 paragraph 1 states that "the child is a person under 18 (eighteen) years, including the unborn child".

From the definition of children as defined in Article 1 paragraph 1 of Law Act, it is known that a person can be called the children if they meet the following requirements: ${ }^{13}$

- There are 18 (eighteen) years; The phrase "Not aged 18 (eighteen) years" in Article 1 paragraph 1 of Act No. 35 of 2014 on amendments to the Act No. 23 of 2002 on the protection of children the same as the phrase "under the age of 18 (eighteen) in article 1 of the Convention on rights of the child which has been ratified by Act No. 5 of 1998.

- Includes children who are still in the womb. To give the meaning of the phrase "includes children who are still in the womb" in article 1 paragraph 1 of Act No. 35 of 2014 on the protection of children to be linked to article 2 of the Civil Code which states that "the child in the womb of a woman, is considered as having been was born, when the interests of the child so desire ".

- Under the Convention on the Rights of Child. Article 1 of the Convention the Rights of the Child states that "for the purposes of this convention then, a child means every human being below the age of 18 (eighteen) years unless under the Act applicable to the child, majority is attained earlier". Child Rights Convention (Convention On The Rights of the Child), Resolution No. 109 of 1990, which was ratified by presidential decree No. 36 of 1990 and be one of the considerations establishment Act No. 11 of 2012 on Child Criminal Justice System.

- Based on Act No. 11 Of 2012 About Child Criminal Justice System. Article 1 paragraph 1 that the Criminal Justice System Children regulated in Act No. 11 of 2012 is a settlement system of the process of "children in conflict with the law". "Children in conflict with the law" referred to by Act No. 11 of 2012 on Child Criminal Justice System, consisting of: 1) Children in conflict with the law, hereinafter referred to child is a child over the age of 12 (twelve) years, but not yet the age of 18 (eighteen) years who allegedly committed crimes (Article 1 paragraph $3)$; 2) Children who are victims of criminal offenses, hereinafter referred to child victims are children under 18 (eighteen) years of experiencing physical, mental, and / or economic loss caused by crime (Article 1 paragraph 4); 3) Kids who witness acts of criminal that hereinafter referred to child witness is a child under 18 (eighteen)

\footnotetext{
${ }^{12}$ Act No. 4 of 1979 on Child Welfare Chapter I Article 1 paragraph 2.

${ }^{13}$ R.Wiyono 2016 Sistem Peradilan Pidana Anak Di Indonesia Jakarta: sinar grafika p.12.
} 
years to provide information for the purpose of investigation, prosecution and trial court about a parker criminal heard, seen and / or experienced by the individual (Article 1 point 5). ${ }^{14}$

\subsection{Application of the law on criminal acts which is conducted traffic offenses by minors}

Adoption of the law on traffic offenses committed by minors are as follows:

- Omission of the violation. It is very commonplace become an everyday sight that the number of traffic violators is not counted again. The offenders are mostly dealt with by the police.

- Repression is not the maximum. Action which is not maximal. There are several reasons why the officer did not leverage against traffic violators, the offender still common mistake is unforgivable, officials take advantage of these offenses.

- Repression maximum. Maximum action. In some cases the police, in the field willing to take decisive action is motivated by several factors, namely: blatant violator, underestimate the appeal officer, the command of the commander that all violators of traffic at certain locations and must be dealt with firmly (given the maximum sentence).

Criminal sanctions imposed on the child should be based to the right, justice, and child welfare. The imposition of criminal or the act which accountable and beneficial for children. The judge shall consider the situation of children, the state house, state of the environment, and social counselors report.

Children who are no older than twelve (12) years, although with a criminal offense can not be put on trial the child. Such things are based on sociological considerations, that a child who has not aged twelve (12) years it has not been able to account for his actions. A child who has not aged twelve (12) years and with a criminal offense shall be subject to criminal sanctions and sanctions action. To determine whether to the child will be dropped criminal or actions, the judge considered light weight criminal offense committed. In addition, it is also taken into account; the situation of children, household circumstances of parents / guardians / foster parents, the relationship between family members, and the state of the environment. Besides, the judge also pay attention social counselors report.

\subsection{Police efforts in tackling past violations which is committed by minors.}

Regarding Traffic violation, as stipulated in Act No. 22 of 2009 on Traffic and Transportation Section 1 that Traffic and road is a unified system consists of Traffic, road freight, network traffic and road transport, infrastructure Traffic and road transport, vehicle, driver, road users, as well as management.

Traffic Violations still frequently occur in the city of Cirebon ironically infringement precisely dominant do students in uniform, the lack of their knowledge of traffic rules

\footnotetext{
${ }^{14}$ Republic of Indonesia Act No. 11 of 2012 on the Criminal Justice System Child Chapter I Article 1 paragraph 2
} 
make them frequent violations and also the life of those who have not enough to have a driver's license (driving license) is one of the requirements of completeness in drive. In terms of efforts to cope with the behavior of school children who do not obey, and sometimes engage in traffic violations because they are not old enough to have a driver's license, the apparatus in this case the Traffic police should make efforts. As proposed by EH Sutherland and Cressey there are two methods used are: ${ }^{15}$

- Preventive efforts. Crime prevention, preventive done to prevent or the emergence of the first crime. Crime prevention is better than trying to educate criminals become better return, as the slogan in criminology that efforts to repair and directed from happening again repeat crimes. Very reasonable when preventive efforts prioritized for preventive measures can be done by anyone without a special expertise and economical.

Efforts made in tackling police Traffic violations committed by minors are as follows:

- To disseminate socialization orderly traffic in schools

- Participate and implement school activities, namely police apparatus who became Inspector of Ceremony in schools

- Cultivate students to become school safety patrol

- Improving knowledge orderly traffic and quiz competitions about traffic

- Enforcing the law: implementing the control to students who do not meet the requirements of driving in cooperation with the department of education and the school.

- Efforts repressive. A repressive measure is a crime prevention efforts as conceptional taken after the occurrence of the crime. Tackling with repressive efforts intended to take action against the perpetrators in accordance with the act and fix it again so that they are aware that the act of doing an unlawful act and the harm to the community, so it will not repeat it and other people are not going to do given the sanctions that will bear very heavy.

When in an attempt to breach the Traffic carried by minors in the city of Cirebon in a preventive way still found a lot violations Traffic then in this case police should make an effort repressive for actioning school children who commit violations in order to have the effect of plentiful perceived by children commits an offense and not to repeat his actions again that the police do:

- Ticket is evidence of violations. The function itself as a invitation ticket to a child who commits an offense and attend a hearing in court the country, as well as alatbukti forfeiture of items seized by the child in violation to the police.

- Foreclosure because the school children have not SIM (driving license) they are underaged look is enough to have a license.

- Strikes done to children who violate the traffic but promised will not be in violation again with make written statement that will not break again.

As for the role of the police against Traffic violation committed by minors, namely:

\footnotetext{
${ }^{15}$ Romli Atmasasmita 1995 Teori dan Kapita Selekta Kriminologi Bandung teresco p.66
} 
- Carry out enforcement activities regularly in operations regularly in schools.

- Installing the banners call on the traffic.

- Disseminate brochures on traffic.

\section{Closing}

\subsection{Conclusion}

From the results of research and discussion can be summarized as follows:

- Legal protection of motorists under the age of criminal acts against traffic violations that should criminal sanctions imposed on the child must be based on truth, justice, and child welfare. Criminal punishment or actions to be accountable and beneficial for children. The judge shall consider the situation of children, the state house, state of the environment, and social counselors report. Children who are no older than twelve (12) years, although with a criminal offense can not be put on trial the child. Such things are based on sociological considerations, that a child who has not aged twelve (12) years it has not been able to account for his actions. A child who has not aged twelve (12) years and with a criminal offense shall be subject to criminal sanctions and sanctions action. To determine whether the child will be dropped criminal or action, the judge considered light weight criminal offense committed. In addition, it is also taken into account; the situation of children, household circumstances of parents / guardians / foster parents, the relationship between family members, and the state of the environment. Besides, the judge aslos pay attention social counselors report.

- The effort and the role carried out by the police in tackling traffic offenses committed by minors namely: a. Preventive measures, this effort is the first step taken by the police to tackle by traffic police on violations committed by school children, by way of orderly trafficdo socialization counseling in schools, so that they notion of good and right. $b$ drive. Repressive efforts, these efforts are taken by the police to take action directly by minors who commit traffic violations prevalent and use to give effect to the minors which done offense.

\subsection{Suggestion}

- The need for extension or dissemination to the school children which is connected with traffic rules so that no traffic violation case committed by minors in the city of Cirebon and created an orderly in traffic on the procedure that safety in traffic.

- Presumably the judge overseeing the child in deciding the case to the child can see the interest of the child based justice and humanity point of view.

- The role of parents is crucial in a child's development by parents should supervise more by minors when driving and pay attention to all activities to the children in an atmosphere that was surrounding environment. Besides it is need for parents gives insight to cross on the child in accordance with procedures and applicable laws. 


\section{Bibliography}

[1] Achmad Ali 1997 Menguak Takbir Hukum,(Jakarta : Grafindo persada

[2] Act No. 11 of 2012 on Criminal SistemPradilan Children

[3] Act No. 22 of 2009 on Traffic and Transportation

[4] Act No. 4 of 1979 on Child Welfare

[5] Darwan Prinst 1997 Hukum Anak di Indonesia PT. Citra Aditya Bakti Bandung .

[6] Ediwarman 2014 Penegakan Hukum dalam Perspektif Kriminologi Genta Publishing Yogyakarta

[7] Leden Marpaung 2011 Proses Penanganan Perkara Pidana (Penyidikan dan Penyelidikan) Cetakan Ketiga Jakarta Sinar Grafika.

[8] Markas Besar Kepolisian Negara Republik Indonesia Akademi Kepolisian 2009 Fungsi Teknis Lalu Lintas Semarang: kompetensi Utama.

[9] Moeljatno 2008 Asas-Asas Hukum Pidana Jakarta: Rieneka Cipta.

[10] Poerwadarminta 2002 Kamus Besar Bahasa Indonesia Jakarta: Balai Pustaka .

[11] R.Wiyono 2016 Sistem Peradilan Pidana Anak Di Indonesia Jakarta: sinar grafika

[12] Republic of Indonesia Act No. 11 of 2012 on the Criminal Justice System Child

[13] Romli Atmasasmita 1995 Teori dan Kapita Selekta Kriminologi Bandung teresco 